\title{
Kepemimpinan Wanita di Indonesia Perspektif Budya dan Agama
}

\author{
Rahmani Timorita $Y$.
}

The following article describes the leadership of woman in Indonesia in culture and religion perspective. Entering reformation era now the role of Indonesian woman will change and increase bacause of the opening of opportunity to woman to participate in all aspect of pubic sphere of life, especially in the context of Indonesian leadership. Based on short descripton afore-mentioned, accoding to the author of this article, it is clear that woman in Indonesia can role strategic in puiblic sphere and becomes a member of legislative. So Indonesian woman can play and takes part in an important role toward nation, state and society.

$\mathrm{K}^{\mathrm{s}}$ ontroversi mengenai pantas tidaknya perempuan menjadi pemimpin merupakan diskursus usang yang tidak upto-date lagi. Paradigma lama yang menempatkan perempuan hanya sebagai ibu rumah tangga sekedar mengurusi urusan domestik harus dibuang jauh-jauh dan diganti konsep kemitrasejajaran yang menempatkan perempuan boleh menjadi. pemimpin dalam kehidupan publik.

Peristiwa penting Pemilihan Umum 2004 akan segera berlangsung pada bulan April mendatang. Ada banyak perubahan besar dalam sistem pemilu kali ini, salah satunya adalah keterwakilan perempuan sebesar 30 persen sebagai calon anggota legislatif seperti diatur dalam UndangUndang Nomor 12 Tahun 2003 tentang Pemilu. Gaung Pemilu 2004 yang berderu keras merupakan momentum yang tepat untuk menunjukkan eksistensi peran perempuan dalam politik dan kebangsaan. Keberadaan perempuan sebagai anggota legislatif merupakan metode yang tepat guna mengartikulasikan kepentingan perempuan yang selama ini termarginalkan serta berada dalam hegemoni maskulin.

Selama ini, besarnya jumlah pemilih perempuan tidak mempengaruhi kebijakan dan program pemerintah dalam melindungi kepentingan kaum perempuan. Tidak banyak organisasi-organisasi di Indoniesia yang menyuarakan aspirasi perempuan dan mengartikulasikan kepentingan perempuan, baik itu menyangkut isu politik, sosial, maupun non politik. Konstruksi sosial bangsa Indonesia ikut berperan dalam memandulkan peran politik perempuan. Perempuán ditekan untuk tidak berbicara secara terbuka.

Memang sejak dulu telah ada di benak masyarakat sebuah sistem paktriarkhi yang menempatkan posisi pria dalam hirarki yang lebih tinggi. Pria dianggap lebih mampu dan layak menjalankan peran-peran di sektor publik. Budaya inilah kemudian menempat- 
kan pria dalam posisi di atas dalam struktur masyarakat kita.'

Di sisi lain, masyarakat Indonesia yang mayoritas Islam, sebagian besar terutama masyarakat awam masih memahami teksteks ajaran agama yang ditafsirkan dalam perspektif "kepentingan" maskulin, sehingga muncul pemahaman yang dikotomis terhadap peran lelaki dan perempuan, antara peran publik dan domestik, superior dan inferior. $^{2}$

Atas nama agama padahal demi kepentingan politik sesaat peran perempuan dalam kehidupan publik sering berusaha dieliminasi (contohnya, saat Megawati akan menjadi presiden). Hal itu dilakukan pemuka agama yang notabene memiliki basis massa riil. Sehingga, opini publik terpengaruhi bahwa yang berhak menjadi pemimpin dalam kehidupan publik, apalagi negara, hanyalah kaum maskulin. Realitas bercerita lain, tatkala Megawati terpilih menggantikan Gus Dur sebagai presiden, banyak diantara tokoh tersebut yang menyatakan tidak masalah seorang presiden bukan laki-laki. Kemudian apakah dengan fakta tersebut telah selesai perdebatan tentang pemimpin wanita di Indonesia? Porsi 30 persen pada kelompok perempuan, apakah sebagai indikasi budaya kepemimpinan Indonesia mulai berpihak kepada kelompok yang semula minoritas?

Pertanyaan lain yang kemudian muncul adalah bagaimanakah kedudukan wanita, khususnya wanita muslim, dalam kancah kemasyarakatan (politik) di negara Indonesia? Benarkah nilai-nilai patriarkhi telah menghalangi perempuan untuk menduduki jabatan tertinggi di negeri ini? Atau disebabkan oleh pemahaman teks-teks keagamaan yang membedakan secara tegas antara pria dan wanita? Tulisan ini akan mencoba membahas secara ringkas persoalan-persoalan tersebut dengan fokus telaahan kepemimpinan wanita di Indonesia perspektif budaya dan agama.

\section{Pria dan Wanita dalam Sorotan Mufasir}

Untuk mengawalinya, akan dipaparkan beberapa nas yang memungkinkan munculnya berbagai interpretasi dalam memahaminya, yang berhubungan dengan asal kejadian wanita dan hak-hak wanita dalam Islam. Berbedakah asal kejadian perempuan dan laki-laki? Ayat al-Qur'an yang biasa dijadikan rujukan tentang wanita adalah Surah an-Nisa ayat 1, yang artinya:

"Hai sekalian manusia bertaqwalah kepada Tuhanmu yang telah menciptakan kamu dari nafs yang sama dan daripadanya Allah memperkembangbiakkan lelaki dan perempuan yang banyak."

Pemahaman yang bersifat dikotomis itu karena perbedaan dalam memahami lafaz nafs pada ayat tersebut. Mufasir mutaqaddimun (terdahulu), sebagaimana yang ditulis oleh M. Quraish Shihab, memahami lafaz tersebut dengan makna Adam, sehingga disimpulkan bahwa istri Adam (perempuan) diciptakan dari Adam itu sendiri. ${ }^{3}$ Mereka juga menambahkan bahwa istri Adam (perempuan) diciptakan dari tulang rusuk sebelah kiri dan bengkok.

1 Tabloid Mingguan Skandal. "Presiden Wanita atau Pria Bukan Persoalan". No. 12 Tahun | 26 Mei 1999.

2 Penelitian tentang bagaimana ahli-ahli tafsir klasik dan kontemporer memahami dan menafsirkan ayat-ayat yang terkait dengan wanita, lebih lanjut lihat llyas Yunahar. Feminisme dalam Kajian Tafsir Klasik dan Kontemporer. Yogyakarta: Pustaka Pelajar, 1997.

${ }^{3}$ M. Quraish Shihab. "Konsep Wanita Menurut Qur'an, Hadis dan Sumber-sumber 
Karena itu wanita bersifat bengkok (tidak lurus). ${ }^{4}$ Pemahaman semacam itu telah menimbulkan image bahwa wanita serba kurang dibanding lelaki, mereka telah menjadi penyebab Adam terlempar keluar surga, yang pada akhirnya memunculkan inferioritas. ${ }^{5}$ Sedang mufasir muta-akhirin (kontemporer) memahami lafaz nafs sebagai jenis. ${ }^{6}$ Interpretasi semacam ini menunjukkan bahwa Allah menciptakan dari sifat dan esensi yang sama dengan pria, ${ }^{7}$ serta menunjukkan bahwa seluruh manusia (ielaki dan perempuan) memiliki asal-usul yang sama. ${ }^{8}$ Pandangan bahwa terdapat persamaan unsur kejadian lelaki dan perempuan diperkuat nas (teks) lain seperti surah al-Isra': $70^{\circ}$, al-Imron: $195^{\text {to }}$

Islam tidak mengajarkan pandangan yang dikotomis antara pria dan wanita. Kalau ada perbedaan, maka itu hanyalah akibat fungsi dan tugas-tugas utama yang dibebankan Tuhan kepada masing-masing jenis kelamin itu, sehingga perbedaan yang ada tidak seharusnya mengakibatkan yang satu merasa memiliki kelebihan atas yang lain. Pada prinsipnya, Islam mengajarkan persamaan antara manusia. Perbedaan yang digarisbawahi dan yang kemudian meninggikan atau merendahkan seseorang hanyalah nilai pengabdian dan ketakwaannya kepada sang Khalik.

Persamaan kedudukan (derajat) yang diberikan al-Qur'an terhadap pria dan wanita menuntut konsekuensi adanya perbedaan hak-hak antara keduenya, termısuk hakhak kepemimpinan. Hak-hak perempuan secara umum digambarkan dalam surah anNisa' ayat 32 , yang artinya:

"Bagi lelaki hak/bagian dari apa yang dianugrahkan kepadanya/diusahakannya, dan bagi perempuan hak bagian dari apa yang dianugrahkan kepadanyal diusahakannya."
Di antara teks yang dijadikan acuan tentang boleh-tidaknya kepemimpinan wanita adalah ayat 34 surah an-Nisa', yang artinya:

"Lelaki adalah pemimpin (qawwamuuna) bagi kaum wanita".

Perkataan "qawwamuuna" dalam ayat ifu sering diartikan sebagai pemimpin. Sehingga dipahami, lelaki adalah pemimpin wanita. Hal ini menurut Fazlur Rahman seperti yang dituliskan Naqiyah Mukhtar,

ajaran Islam" dalam Lies M. Marcoes. Natsir dan Johan Hendrik Meuleman. Wanita Islam Indonesia dalam Kajian Tekstual dan Kontekstual. Jakarta: INIS, 1991. h. 4.

${ }^{4}$ Ibid., h. 5.

5 Transkrip wawancara. "Feminisme dan al-Qur'an: Percakapan dengan Riffat Hasan, dalam Ulumul Qur'an. Vol. 11. 1991. h. 86.

'Quraish Shihab. "Konsep....". h. 5.

${ }^{7}$ Murtadha Muththahari. Hak-Hak Wanita dalam Islam. cet. I. Jakarta: Lentera. 1997. h. 75.

${ }^{8}$ Amina Wadud Muhsin. Wanita di dalam al-Quran. Bandung: Pustaka. 1994. h. 75.

9 "Dan sesungguhnya telah kami muliakan anak-anak Adam, kami angkat mereka di dataran dan di lautan, kami beri mereka rezeki dari yang baik-baik dan kami lebihkan mereka dengan kelebihan yang sempurna atas kebanyakan makhluk yang telah kami ciptakan."

10 "Maka Tuhan mereka memperkenankan permohonannya (dengan berfirman): "Sesungguhnya Aku tidak menyianyiakan amal orang-orang yang beramai di antara kamu, baik laki-laki atau perempuan, (karena) sebagian kamu adalah turunan dari sebagian yang lain. Mereka orang-orang yang berhijrah, yang diusir dari kampung halamannya, yang disakiti pada jalan-Ku yang berperang dan yang dibunuh, pastilah akan Kuhapuskan kesalahan-kesalahan mereka dan pastilah Aku masukkan mereka ke dalam surya yang mengalir sungai-sungai di bawahnya sebagai pahala di sisi Allah. Dan Allah pada sisiNya pahala yang baik." 
karena memiliki kelebihan, yaitu kelebihan yang diperoleh dalam pengalaman hidup dan kearifan praktis sebagai faktor yang berfungsi sosial dan sebagai pencari nafkah." Konsekuensinya, ayat ini memposisikan yang memimpin dan yang dipimpin. Penafsiran ini tidak salah, tetapi masalahnya kalau hal ini-dijadịkan landasan ketidaksejajaran perempuan dan laki-laki, sudah barang tentu merupakan sebuah upaya untuk menggeneralisasikan misi alQur'an. Yang pada akhirnya wanita dipandang inferior dari laki-laki. Padahal perkataan gawwaamuun yang diartikan pemimpin menurut penafsir kontemporer, sebagaimana ditulis Etin Subardini, sebagai seorang yang bertanggung jawab untuk memelihara barang maupun orang. Dengan kata lain, lelaki bertanggung jawab mengayomi perempuan dan tidak ada hubungannya dengan satu pihak superior dan pihak lain inferior. ${ }^{12}$

Disamping itu pandangan bahwa pria adalah qawwamuun atas perempuan tidak dapat diterapkan secara universal untuk dijadikan dasar melarang perempuan menjadi pemimpin (kepala negara), karena surat an-Nisa' ayat 34 tersebut berbicara dalam konteks keluarga. Selain itu, menurut M.Quraish Shihab, kata ar-Rijal dalam ayat tersebut (ar-rijaalu qawwaamuuna 'ala annisa'), bukan lelaki secara umum, tetapi lebih menunjukkan pada arti suami). ${ }^{13}$ Pandangan ini menguatkan pendapat bahwa ayat tersebut memang membicarakan tentang para istri dan kehidupan rumah tangga. Di sisi lain, banyak ayat yang mendukung keberadaan hak-hak politik (kepemimpinan) bagi wanita antara lain surah al-Taubah ayat $71 .{ }^{14}$

Disamping surah an-Nisa' ayat 34 di atas, teks lain yang dijadikan acuan boleh tidaknya kepemimpinan wanita adalah sabda Rasulullah SAW yang intinya, "tidak akan bahagia satu kaum yang menyerahkan urusan mereka kepada perempuan". Dari segi sanadnya, hadis ini tergolong hadis ahad yang diriwayatkan oleh sebagian kecil sahabat. Karenanya ia tidak mengikat dan tidak perlu dijadikan dasar hujjah. ${ }^{15}$

Dari segi isi, konteks hadis tersebut berbicara tentang pergantian raja Kisra ke tangan perempuan yang telah diketahui ketidakmampuannya memimpin kerajaan besar seperti Persia. ${ }^{16}$ Dengan kata lain ini tidak berlaku umum. Di sisi lain, hadis tersebutjuga bertentangan dengan kisah ratu Balqis dalam al-Qur'an yang berhasil memimpin rakyatnya menuju keimanan dan kesuksesan, dengan kecerdasan dan kearifannya. ${ }^{17}$

Dari teks-teks al-Qur'an dan Hadis di atas dapat dipahami bahwa islam meman-

"Naqiyah Mukhtar. "Telaah terhadap Perempuan Karier dalam Pandangan Hukum Islam". dalam Jamal D. Rahman et., all., (ed) Wacana Baru Figih Sosial: 70 Tahun KH. Ali Yafie. Bandung: Mizan dan Bank Muamalat. 1997, h. 167.

${ }^{12}$ Etin Subardini, "Teologi Perempuan dalam Wacana Islam", dalam Dadang S. Anshori, Op.cit., h. 110.

${ }^{13} \mathrm{M}$. Quraish Shihab. Wawasan al-Qur'an: Tafsir Maudlu'l Atas Pelbagai Persoalan Umat. Cet. III. Bandung: Mizan, 1996. h. 314

14 "Dan orang-orang yang beriman, Lelaki dan Perempuan, sebagian mereka adalah menjadi penolong bagi sebagian yang lain. Mereka menyuruh (mengerjakan) yang ma'ruf, mencegah dari yạng munkar, mendirikàn. sembahyang, menunaikan zakat dan mereka ta'at kepada Allah dan Rasul-Nya. Mereka itu akan diberi rahmat oleh Allah Sesungguhnya Allah Maha Perkasa lagi Maha bijaksana." h. 169.

${ }^{15}$ Naqiyah Mukhtar, "Telaah terhadap.....

${ }^{16}$ Syaikh Muhammad al-Ghazali, Studi Kritis atas Hadis Nabi SAW, Antara Pemahaman Tekstual dan Konteksual. Cet. II. Bandung: Mizan. 1992. h. 65.

${ }^{17} \mathrm{lbid}$. h. 66. 
dang sama antara pria dan wanita, tidak ada istilah superior dan inferior. Kedudukannya memiliki posisi dan hak yang sama untuk turut berpartisipasi mengaktualisasikan fungsi kekhalifahannya.

\section{Hak-hak Politik Perempuan}

Hak untuk berpolitik artinya hak untuk berpendapat, hak untuk menjadi anggota lembaga perwakilan dan hak untuk memperoleh kekuasaan, seperti mernimpin lembaga formal; organisasi, partai dan presiden. ${ }^{18}$ Hak-hak politik perempuan tentunya akan terkait dengan hak asasi manusia secara umum. Hak asasi ini dimiliki tanpa membedakan dasar bangsa, ras, agama begitu pula jenis kelamin. Karena dasar dari hak asasi ini, adalah bahwa manusia memperoleh kesempatan untuk berkembang sesuai dengan bakat dañ citacitanya. ${ }^{19}$

Di Indonesia, persoalan hak asasi ini terangkum dalam UUD 1945, menyangkut hak atas kebebasan mengeluarkan pendapat, kebebasan berkumpul, berserikat (pasal 28), kebebasan beragama (pasal 29) dan hak atas kehidupan layak (pasal 27: 2). Dalam pembahasan politik, nilai yang paling dominan adalah nilai kekuasaan. Orang atau kelompok yang ingin mencapai kekuasaan mutlak setidaknya harus memenuhi ketentuan dan penguasaan atas kemampuan (ability), kecakapan (capacity), kesangg:dpan (faculty) dan kepandaian (skill).

Kesetaraan dalam kesempatan antara laki-laki dan perempuan Indonesia untuk terjun ke arena politik sebenarnya sudah mendapat payung legalitas dari aturan Hak Asasi Manusia (HAM) dan UUD 1945. Sehingga persoalan yang tersisa adalah kapasitas kemampuan masing-masing individu untuk diapresiasikan dalam kehidupan politik. Sebenarnya, fenomena seperti ini bukan "barang" baru dalam Islam karena pada jaman kerasulan Muhammad saw. pun muncul tokoh Aisyah r.a. yang aktif memantau keadaan. umat, Hafshah yang sangat prihatin atas krisis yang melanda kekhalifahan Islam, dan tokoh-tokoh wanita lainnya yang senantiasa berinteraksi dengan masyarakat.

Demikian pula di Indonesia, sekarang ini telah terjadi tuntutan untuk emansipasi wanita termasuk dalam kepemimpinan di bidang politik dan kenegaraan. Tetapi di lain pihak ternyata wanita belum siap dan mampu memasuki arena tersebut karena faktor-faktor pendidikan, nilai-nilai budaya, psikologis, agama maupun pengalaman organisatoris yang belum memadai. Akibatnya terjadi ambivalensi yang perlu dibenahi dan dikritisi untuk memberdayakan kepemimpinan wanita.

Penetrasi wanita dalam lembaga legislatif pada tingkat daerah maupun nasional ditentukan oleh posisi mereka dalam partai politik. Walaupun pemimpin partai politik selalu menyuarakan kehendak untuk memberikan prioritas terhadap wanita, dalam kenyataannya wanita cenderung tidak terwakili secara proporsional dalam posisi elit partai, sehingga perempuan juga sedikit yang memegang jabatan puncak di partai politik. Keadaan demikian tidak hanya terdapat dalam partai politik saja, tetapi kemudian juga berimbas pada komposisi keanggotaan di lèrnbaga legislatif yang tidak proporsional.

Dari sedikit jumlah politisi wanita tersebut, bila ditelusuri lebih cermat tidak

${ }^{18}$ Chusnul Mariyah. Kepemimpinan Politik Perempuan, dalam Jurnal Perempuan edisi 07 Tahun 1998, h. 16.

${ }^{19}$ Mariam Budiarjo. Dasar-dasar IImu Politik, Jakarta: Gramedia. 1998, hl, 120. 
Kepemimpinan Wanita di Indonesia Perspektif Budya...; Rahmani Timorita Y.

seluruhnya pantas dibanggakan. Ketidakterwakilan ini menghambat kesempatan yang dimiliki wanita untuk menyuarakan aspirasi dan kepentingan, serta tersumbat-nya peluang untuk mempengaruhi kebijakan politik sosial. Dalam kaitan ini Handayani mengatakan ada tiga profil kepemimpinan wanita di bidang politisi, yaitu:

1. Achieved woman politician. Model pemimpin politik wanita yang semacam ini adalah model wanita yang menekuni dunia politik karena memiliki kemampuan intelektual dan organisatoris yang mandiri. Kasus kemampuan Margareth Tatcher yang menjadi perdana menteri di Inggris selama tiga periode berturut-turut, Golda Meir perdana menteri Israel pada Tahun 1969, dan Gro Herlem perdana'menteri Norwegia pada tahun 1981 merupakan contoh yang menarik untuk menunjukkan bahwa wanita juga memiliki kualitas sumberdaya yang memadai untuk berkiprah di arena politik. Kelompok politisi semacam ini adalah kelompok yang pada umumnya sejak usia muda telah menekuni dunia politik, :

2. Ascribed woman politician. Model semacam ini adalah model wanita yang memperoleh jabatan politik bukan karena mereka memang sepenuhnya memiliki kemampuan politik yang prima atau karena usahanya secara mandiri, tetapi mereká mendapatkan kedudukan politik karena hubungannya dengan laki-laki tertentu yang memiliki kedudukan politis yang penting. Nampaknya sebagian besar politisi wanita yang ada menempati posisi ini. Sosok Indira Gandhi, Sheikh Hasina Wajed, Benazir Bhutto, dan Corry Aquino adalah beberapa contoh politisi wanita model ini.
3. Politisi wanita yang mencapai kedudukan politik karena mempunyai kolusi dengan birokrasi. Karena birokrasi yang masih bersifat patrimonial, maka politisi wanita model ini mempunyai patron. Patron adalah elitelit politik. Hubungan antara patron dengan politisi wanita yang berperan sebagai klien menunjukkan, bahwa seorang klien akan selalu mencari patronnya untuk minta pertolongan. Seorang patron akan dipandang sebagaj tumpuhan dari sumber pemenuhan materiil dan spiritual dari kliennya. Patron harus selalu ditaati, dihormati dan tidak boleh ditentang. Sebaliknya seorang klien merupakan pelindung, pendukung, serta tulang punggung yang setia terhadap kepentingan patronnya. ${ }^{20}$

Secara sederhana peran wanita dalam kehidupan politik adalah kegiatan untuk ikut aktif dalam partai politik, kelompok kepentingan, dan lembaga-lembaga legislatif maupun eksekutif. Di lembaga eksekutif, jumlah wanita yang menduduki posisi tinggi dalam pemerintahan masih jauh dari harapan. Bila pada periode 1945-1950, Indonesia pernah mempunyai Menteri Pendidikan dan Menteri Perburuhan yang dijabat oleh politisi wanita, maka lima puluh tahun kemudian pertambahannya belum begitu berarti, karena pada periode 19982003, hanya tiga wanita yang dapat menempati posisi elit pemerintahan yaitu Menteri Peranan wanita, Menteri Sosial, dan Menteri Pertanian, dan jumlah ini berkurang dua posisi satu dalam kabinet reformasi sehingga hanya tinggal dua posisi, yaitu Menteri Peranan Wanita dan Menteri Sosial.

${ }^{20}$ Trisakti Handayani, Kepemimpinan Wanita dalam Bidang Politik dan Kenegaraan, dalam Islam dan Problem Gender, Yogyakarta: Aditya Media. 2000. h. 192-193. 
Dilihat dari pembagian kerja secara seksual, penempatan wanita pada jaman kementerian tersebut justru semakin menegaskan ketimpangan, bahwa dalam lingkup birokrasi pemerintahpun peran-peran domestik tetap melekat pada wanita.

Kondisi serupa juga dapat ditemukan dalam komposisi keanggotaan legislatif. Jumlah wanita yang menjadi anggota DPR/ MPR dari periode 1971-1998 meskipun hampir selalu mengalami kenaikan, tetapi jumlah ini tidak pernah mencapai 20 persen. Bila pada pemilu 1971 wanita yang menjadi anggota DPR/MPR hanya 31 orang, maka pada tahun 1992 jumlah itu naik menjadi 53 orang, dan pada tahun 1998 atau bahkan hasil pemilu tahun 1999 tidak jauh berbeda dengan tahun-tahun sebelumnya. Kenyataan ini tentu saja sangat memprihatinkan dan kontradiktif dengan komposisi pemilih yang justru mayoritas wanita $(57 \%)$, dan lebih ironis lagi posisi politik yang ditempati wanita saatini belum merupakan perjuangan politik dari wanita sendiri, namun lebih merupakan "aksesoris politik" belaka. ${ }^{21}$

Ambivalensi kepemimpinan terlihat bila dikaitkan dengan profil kepemimpinan wanita karena potret pemiripin politik wanita Indonesia saat ini masih terpaku pada model kedua, yaitu sebagai "acribed women politician" atau bahkan pada model "politisi wanita yang mencapai kedudukan politik karena mempunyai kolusi dengan birokrasi. Wanita Indonesia tampaknya memang belum mempi.jnyai motivasi dar: kompetensi yang cukup memadai untuk terjun ke dunia politik, dan hal ini didukung oleh kondisi wanita Indonesia yang umumnya belum mempunyai latar belakang yang cukup untuk terjun sebagai politisi, baik yang diperoleh melalui pendidikan maupun pengalaman organisasi maupun pemerintahan.

Masalah kultural dan psikologis adalah dua hambatan terbesar penyebab "wanita dan kegiatan non domestik" sulit berdampingan, termasuk didalamnya adalah kegiatan politik. Dalam kehidupan masyarakat masih tertanam cukup kuat bahwa segala kehidupan yang berkaitan dengan politik adalah identik dengan dunia pria. Hal seperti itu sebenarnya juga terjadi di beberapa Negara Barat, bahwa politik inheren dengan image yang menyertai maskulin. Kondisi ini sempurna manakala kaum pria banyak yang belum siap menerima kepemimpinan kaum wanita. Untuk Indonesia, nampaknya keadaan ini masih akan bertahan cukup lama, terlebih ketika kita semua maklum bahwa proses menjadi lbu (motherhood), masih merupakan cita-cita tertinggi wanita. Karena itulah, meskipun kemitrasejajaran antara pria dan wanita di Indonesia sudah menunjukkan kemajuan yang cukup bermakna, sejumlah hambatan psikologis dan kultural masih menghadang wanita.

Faktor-faktor lainnya yang dapat dijadikan penyebab minimnya partisipasi politik wanita dalam dunia perpolitikan nasional, adalah: tingkat pendidikan formal wanita yang relatif rendah. Pada tingkat SMTP partisipasi wanita hanya mencapai 38,4 persen. Pada tingkat SMTA partisipasi wanita menjadi 36,2 persen dan pada tingkat PT turun menjadi 32,6 persen. ${ }^{22}$ Kurangnya pemerataan pendidikan pada wanita ini sudah barang tentu dapat mempengaruhi kesadarannya terhadap hak dan kewajibannya sebagai warga negara, yang pada akhirnya menghambat partisipasi wanita dalam dunia politjk. Demikian juga eksistensi agama sementara ini oleh sebagian khalayak juga dianggap sebagai hambatan terhadap wanifa untuk menjadi 
Kepemimpinan.Wanita di Indonesia Perspektif Budya...; Rahmani Timorita Y.

pemimpin politik, meskipun masih menimbulkan kontroversi.

\section{Pemilu 2004 dan Perempuan}

Dalam era reformasi sekarang ini, struktur peranan perempuan Indonesia akan mengalami perubahan akibat transparansi dalam segala aspek kehidupan. Pendidikan dan pengetahuan yang diperoleh kaum perempuan akan memberikan kesadaran kepada mereka tentang kedudukan dan peranannya di masyarakat, karena pendidikan merupakan salah satu faktor yang dapat mendorong kemajuan bangsa dan negaranya. Ungkapan "al-Nisa'imad albilad" (perempuan adalah tiang negara), menunjukkan betapa besar peran, andil, partisipasi, dan keterlibatan langsung kaum perempuan dalam menegakkan suatu bangsa dan negara agar menjadi kokoh dan kuat, adil dan kemakmuran.

Dengan kesadaran dan pengetahuan yang diperoleh, kaum perempuan tidak hanya bisa menjadi ibu rumah tangga atau isteri yang bergerak di wilayah domestik, akan tetapi potensi yang dimilikinya harus dikembangkan. Kesempatan memasuki dunia laki-laki (wilayah publik) mulai terbuka dan semakin lama semakin lebar. Tentu saja ada syarat-syarat yang harus dipenuhi, baik oleh laki-laki maupun perempuan. Pada dasarnya, perempuan dan laki-laki sama, baik kecerdasan otaknya, kemuliaan budi, keluhuran cita-cita, memiliki impian Jan harapan, kekhawatiran dan ketakutan, begitu pula potensi untuk memimpin.

Kaum perempuan di masa kebangkitan bangsa dan perjuangan membela kemerdekaan memiliki kesadaran politik dan keberanian yang luar biasa. Perempuan berani mengambil keputusan-keputusan politik dalam situasi yang serba dibatasi oleh pemerintah kolonial Belanda. Kiprah kaum perempuan dalam masyarakat Indonesia semakin berkembang walaupun secara proporsional jumlahnya belum seimbang dengan jumlah penduduk perempuan secara keseluruhan. Hampir setiap pemilu jumlah perempuan yang terpilih berkisar antara $8 \%-10 \%$. Pendaftaran pencalonan dari masingmasing kekuatan sosial politik lebih dari $10 \%$ calon anggota perempuan. ${ }^{23}$

Dalam pemilihan komisi (lembaga legislatif), minat para anggota perempuan juga masih berkisar pada bidang-bidang yang sering diasosiasikan dengan keperempuan, misalnya komisi yang membidangi masalah Kesra (Komisi VII), yang membahas tentang kesehatan, sosial, BKKBN, dan sejenisnya. Komisi yang paling sedikit diminati anggota perempuan adalah Komisi l yang membidangi politik luar negeri, Pertahanan \& Keamanan, BAKIN, dan Departemen Penerangan. Demikian pula, Komisi APBN yang membahas Anggaran Belanja dan Pendapatan Negara. ${ }^{24}$

Dari kenyataan-kenyataan di atas, dapat dilihat bahwa dalam pengambilan keputusan, khususnya pada taraf nasional, perempuan belum banyak berperan. Tentu saja diharapkan pada hasil pemilu 2004 ada perempuan-perempuan yang berperan dalam pengambilan keputusan pada tingkat nasional. Ada penerapan faktor (klasik) yang menyebabkan kaum perempuan menghadapi situasi dilematis, yaitu ideologi "Adam dan Hawa" dan asumsi bahwa kedudukan kaum perempuan adalah di rumah, dianggap sebagai the second class. Kedua faktor ini ternyata masih banyak "dianut" masyarakat kita (Indonesia).

${ }^{23}$ Melly. G. Tan. Perempuan Indonesia Pemimpin Masa Depan. Jakarta: Pustaka Sinar Harapan, 1991. h. 53.

${ }^{24} \mathrm{Jbid}$., h. 57 
Meskipun hal ini merupakan social construction, akan tetapi telah dilegitimasi dengan mengatasnamakan agama melalui kebijakan-kebijakan birokrasi (pemerintahan).

Berkaitan dengan pemilu dan bertolak dari jumlah pemilih kaum perempuan sebesar $53 \%$, maka pengaruhnya.terhadap hasil pemilu sangat besar. Oleh karena itu, penggunaan hak pilih merupakan proses pemberdayaan politik bagi perempuan menuju negara yang adil, sehingga dapat memperjuangkan aspirasi dan kepentingan kaum perempuan yang nantinya akan dapat mempengaruhi kebijakan-kebijakan yang berperspektif gender, tidak lagi ada diskriminasi dan domestikasi kaum perempuan.

Pada Pemilihan Umum (Pemilu) 2004 tampaknya harapan untuk meningkatkan jumlah wakil perempuan di lembaga legislatif ke jumlah 30 persen belum bisa dipenuhi. Sistem pemilihan proporsional terbuka yang menuntut setiap calon mendapat suara sama dengan bilangan pembagi pemilih (BPP), sementara perolehan suara yang tak mencukupi angka BPP diberikan kepada caleg di urutan teratas, menyebabkan posisi "jadi" dan bukan posisi "sepatu" sangat penting untuk keterwakilan perempuan.

Dengan demikian, peran partai politik sangat penting dalam menentukan apakah perempuan bisa duduk di lembaga legislatif. Dalam jumpa pers yang diadakan bersamasama oleh Cetro dan Kaukus Perempuan Politik Indonesia (KPPI) di gedung Komisi Pemilihan Umum awal Januari lalu, para perempuan yang berada di Parpol dan dinominasikan sebagai caleg oleh partainya menyebutkan hambatan yang mereka rasakan antara lain antara kriteria sangat maskulin yang diterapkan, tidak ada kriteria yang memasukkan kerja khas perempuan; serta yang paling banyak dikemukakan adalah politik uang, yaitu besarnya sumbangan uang yang diberikan kepada partai.

Sementara partai tidak transparan menyebut berapa sumbangan yang diharapkan dari seorang caleg. Tidak kurang dari ketua KPPI Hj. Machfudoh Aly Ubaid dari PPP menyebutkan bahwa laki-laki masih belum mau memberi perempuan kesempatan, ${ }^{25}$

Dalam berbagai pertemuan dengan anggota KPPI juga terungkap pentingnya perempuan berada di posisi kunci di dalam parpol, karena para perempuan tersebut umumnya juga memperjuangkan para perempuan caleg lainnya. Meskipun demikian, hal itu tidak selalu menjamin para perempuan berada pada posisi jadi, karena sedikitnya jumlah perempuan pada posisi kunci di Parpol lebih sedikit lagi perempuan yang duduk dalam komisi seleksi caleg di partai. Melihat perkembangan saat ini dengan memperhitungkan Pemilu 2004, sementara masyarakat masih tertatih-tatih memahami tata cara pemilu, harapan untuk terpenuhinya jumlah 30 persen perempuan di lembaga legislatif akan cukup berat.

Akan tetapi, upaya yang dilakukan selain ini bukan kesia-siaan. Setidaknya, isu keterwakilan perempuan di parlemen bukan lagi isu marginal. Gencarnya kampanye kelompok perempuan mempromosikan keterwakilan perempuan serta melakukan pelatihan di tingkat akar rumput telah membuka jalan bagi perempuan untuk apa yang sebelumnya tidak pernah mereka pikirkan akan mereka masuki, yaitu dunia politik untuk menuju Pemilu 2009.

${ }^{25}$ Ninuk M. Pambudy. "Keterwakilan Perempuan di Politik Cuma Janji Parpol". Dalam Kompas. Senin 9 Februari 2004. 
Kepemimpinan Wanita di Indonesia Perspektif Budya...; Rahmani Timorita Y.

\section{Penutup}

Paparan tersebut menunjukkan bukti konkrit bahwa perempuan tidak boleh terus terkungkung dalam inferioritasnya. Perempuan harus memiliki keharusan untuk mendobrak superioritas maskulin. Seperti fenomena gunung es yang di permukaan kecil, tetapi di bawah sangat besar, itulah gambaran mengenai rumit, pelik, dan banyaknya permasalahan yang berkaitan dengan perempuan. Minimnya program konkret pemerintah dalam mengatasi permasalahan-permasalahan perempuan terbukti dengan begitu banyak kasus pemerkosaan serta pelecehan seksual.

Melihat paparan tersebut, diperiukan wadah untuk mengartikulasikan ekspresi kepentingan perempuan. Untuk melahirkan kebijakan yang berpihak pada perempuan, perempuan harus menjadi bagian dari pembuatan kebijakan tersebut. Sebab, yang lebih paham tentang kebutuhan dan kepentingan perempuan adalah perempuan sendiri. Hal itu merupakan keniscayaan yang harus dihadapi perempuan bila perempuan ingin kepentingan-kepentingan terwadahi.

Dengan menduduki posisi strategis dalam kehidupan publik dan menjadi bagian dari stake holder, perempuan bisa memperjuangkan dirinya sendiri dan sekaligus menunjukkan bahwa mereka tidak berada dalam posisi yang inferior dibandingkan iaki-laki. Menjadi anggota badan legislatif, baik di pusat maupun daerah, sedikit banyak bisa menjawab keresahan kaum perempuan yang tidak terwadahi aspirasinya. Dengan banyaknya jumlah pemilih perempuan dan sumbangsih mereka terhadap masyarakat dan bangsa, sangat pantas bahwa 30 persen, bahkan lebih, anggota legislatif adalah perempuan, yang bukan hanya sekedar janji Parpol atau lips service undang-undang.

\section{Daftar Pustaka}

Al Ghazali. Syaikh Muhammad. 1992. Studi Kritis atas Hadis Nabi saw: antara Pemahaman Tekstual dan Kontekstual. Cet Il. Bandung: Mizan.

Krisnawaty, Taty. 1987. "Gerakan Perempuan dan Demokrasi." dalam Dadang S. Anshori dkk (ed). Membincangkan Feminisme: RefleksiMuslimah atas Peran Sosial Kaum Wanita. Cet I. Bandung: Pustaka Hidayah.

Mar'iyah, Chusnul. 1998. Kepemimpinan Politik Perempuan, dalam jurnal Perempuan. Edisi 07.

Muhsin, Amina Wadud. 1994. Wanita di dalam al-Quran. Bandung: Pustaka.

Mukhtar, Naqiyah. 1997. "Telaah terhadap Perempuan Karier daiam Pandangan Hukum [slam". dalam Jamal D. Rahman et. all. (ed). Wacana Baru Fiqih Sosial: 70 Tahun KH. Ali Yafie. Bandung: Mizan dan Bank Muamalat.

Muthahhari, Murtadha: 1997. Hak-hak Wanita dalam Islam. Cet I. Jakarta: Lentera.

Natsir, Lies M. Marcoes dan Johan Hendrik Meuleman. 1991. Wanita Islam Indonesia dalam Kajian Tekstual dan Kontekstual. Jakarta: INIS.

Purwadi, Agus (Ed). 2000. Islam dan Problem Gender. Yogyakarta: Aditya Media.

Subhan, Zaitunah. 2002. Rekonstruksi Pemahaman Gender dalam Islam. Jakarta: El Kahfi. 
Topik: Kepemimpinan Nasional Pasca Pemilu 2004

Tabloid Mingguan Skandal. "Presiden Yafie, Ali. 1997. Menggagas Fiqh Sosial. Wanita atau Pria Bukan Persoalan". cet. 3. Bandung: Pustaka Hidayah. No. 12 Tahun I. 26 Mei 1999.

\section{$\square \square \square$}

